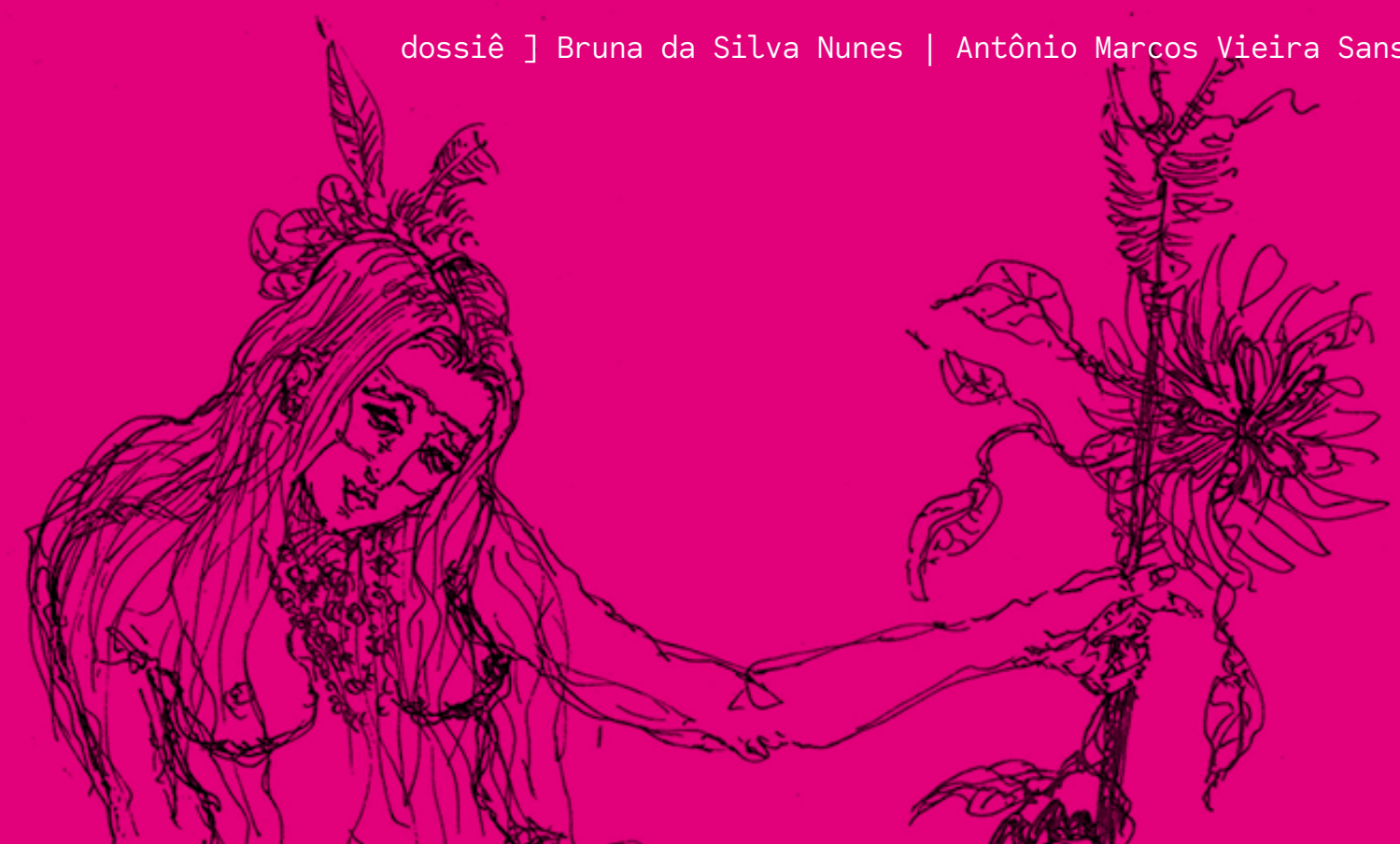

\title{
Péla aparência se enxerga a essência: moda e indumentária no conto machadiano do Jornal das Pamilias
}

Through the appearance one can see the essence: ¿ a fashion and clothing in the Machado de Assis's

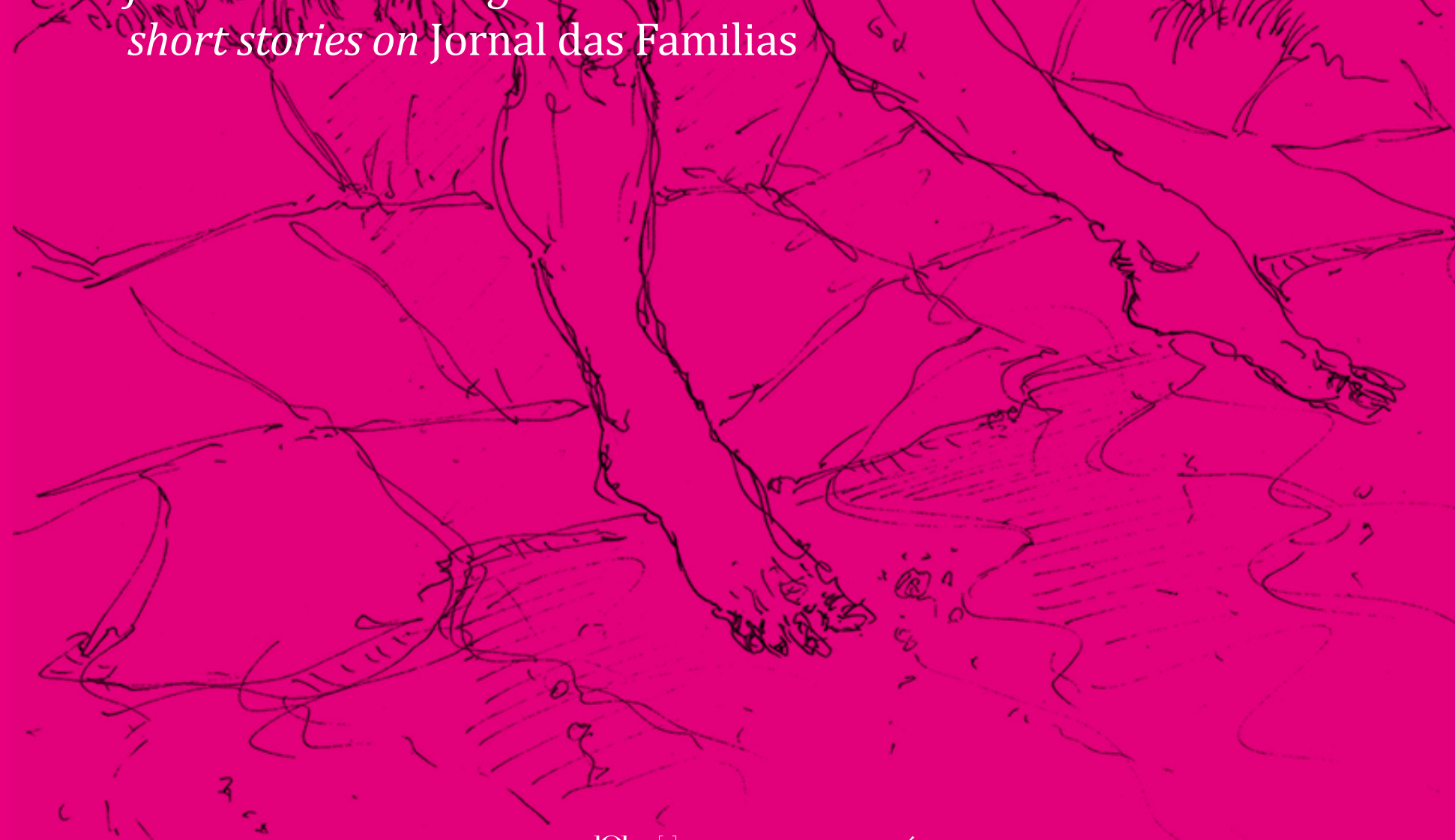




\section{Bruna da Silva Nunes ${ }^{1}$}

ORCID: https://orcid.org/0000-0002-3024-9144

\section{Antônio Marcos Vieira Sanseverino}

ORCID: https://orcid.org/0000-0001-6085-0881

[resumo] 0 presente artigo tem por objeto três contos de Machado de Assis publicados no periódico Jornal das Familias - "Brincar com fogo", "Encher tempo" e "Um esqueleto". Por meio de uma análise formal articulada com a pesquisa em fontes primárias, o trabalho organiza-se a partir de dois objetivos centrais: 1) avaliar a relevância que a descrição de itens da indumentária assume nas narrativas estudadas e 2) observar a relação entre a representação da indumentária e a linha editorial do suporte de publicação dos textos, um jornal voltado para o público feminino. Para tanto, são mobilizados, a título de referencial teórico, os estudos de Souza (1987), Pinheiro (2007) e Salomon (2010), além de outros autores. Entre os resultados obtidos, destaca-se o papel estrutural da descrição do vestuário na construção das personagens, cujas ações são refletidas em sua indumentária.

\section{[palavras-chave] Machado de Assis. Jornal das Familias. Moda. Indumentária. Conto.}

[abstract] This article takes as objects of study three Machado de Assis's short stories published in the newspaper Jornal das Familias - "Brincar com fogo", "Encher tempo" e "Um esqueleto". Through a formal analysis articulated with research on primary sources, the study is organized around two main objectives: 1) evaluating the relevance that the description of clothing items assumes in the narratives studied and 2) observing the relationship between the representation of clothing and the editorial line of the support in which the texts were published, that is, a newspaper aimed at the female audience. Therefore, the studies of Souza (1987), Pinheiro (2007), and Salomon (2010), among others, are mobilized as theoretical references. As a result, we highlight the structural role of the clothing description in the construction of characters, whose actions are reflected in their clothing.

[keywords] Machado de Assis. Jornal das Familias. Fashion. Clothing. Short story.

Recebido em: 06-10-2019

Aprovado em: 04-02-2020

\footnotetext{
${ }^{1}$ Mestre em Literatura Brasileira (UFRGS). Doutoranda em Estudos de Literatura (UFRGS). E-mail: bsnunes91@gmail.com. Lattes: http://lattes.cnpq.br/4687287365483131.

2 Doutor em Teoria da Literatura (PUCRS). Professor associado de Literatura Brasileira no Programa de Pós-Graduação em Letras (UFRGS). E-mail: amvsanseverino@gmail.com. Lattes: http://lattes.cnpq. br/7032901713208920.
} 


\section{Machado de Assis, moda e indumentária}

“Calçava sapatos de duraque, rasos e velhos, a que ela mesma dera alguns pontos." "Um simples vestido branco, de cassa, sem enfeites, tendo ao colo, em vez de broche, um botão de madrepérola, e outro botão nos punhos, fechando as mangas, e nem sombra de pulseira. Era isso no corpo; não era outra coisa no espírito." "Lembrou-me vestir a farda de alferes. Vesti-a, aprontei-me de todo; e, como estava defronte do espelho, levantei os olhos, e... não lhes digo nada; o vidro reproduziu então a figura integral; nenhuma linha de menos, nenhum contorno diverso; era eu mesmo, o alferes, que achava, enfim, a alma exterior." As passagens supracitadas, referências às vestes de Capitu, de Dom Casmurro, Eugênia, de Memórias póstumas de Brás Cubas, e Jacobina, do conto "O espelho", são exemplos significativos de como Machado de Assis lançava mão de elementos da moda e da indumentária para sua elaboração ficcional e de como tais elementos desempenham uma função importante na construção de suas narrativas.

Segundo Gilles Lipovetsky (2009), a moda é baseada em paradoxos, pois a vestimenta tanto pode ajudar a entender a ideologia dominante de uma época quanto a desvendar os traços subjetivos de seu portador; pode ser a indicação para localizar o espaço geográfico que determinada pessoa ocupa, bem como seu ânimo e seu temperamento. Pensando em como essa dinâmica se dá na análise literária, a representação da moda e da indumentária auxilia a inserir o leitor no contexto sócio-histórico representado na obra ao mesmo tempo que tem o poder de contribuir para a constituição das personagens e, por extensão, da trama como um todo.

É importante salientar que os termos moda e indumentária nem sempre se equivalem. Segundo Fausto Viana (2012), indumentária refere-se a tudo aquilo que o ser humano veste, enquanto moda, em um conceito amplo, diz respeito a um fenômeno social de mudança cíclica dos costumes, à aceleração de produção, ao desejo de novidade, às transformações regulares nos diversos setores da vida social ${ }^{3}$. A moda é um fenômeno moderno e ocidental, como aponta Lipovetsky (2009). Neste artigo, trabalhamos com um conceito de moda mais restrito, explorado por Gilda de Mello e Souza, "reservado às mudanças periódicas nos estilos de vestimenta e nos demais detalhes da ornamentação pessoal” (SOUZA, 1987, p. 19). Avaliando esses conceitos, entendemos que a ocorrência de uma representação de indumentária pode trazer conteúdo de moda ou não.

\footnotetext{
3 Síntese composta a partir das leituras de Souza (1987), Calanca (2011), Viana (2012) e Lipovetsky (2013).
} 
Posto isso, este artigo propõe uma leitura dos contos "Brincar com fogo", "Encher tempo" e "Um esqueleto", de Machado de Assis, publicados no periódico Jornal das Familias. Essa leitura tem por intuito analisar como as menções aos itens da moda e da indumentária colaboram com o desenvolvimento das narrativas e como elas se relacionam com a linha editorial do suporte original de publicação dos contos. Para tanto, lançamos mão do método indiciário proposto por Carlo Ginzburg (1989) no ensaio Sinais: raízes de um paradigma indiciário. Em tal texto, o autor discorre sobre o método indiciário, procedimento pautado na observação dos pormenores para obter um exame mais satisfatório do objeto, visto que os resíduos e os "dados marginais" são repletos de informações reveladoras; dessa forma, esses resíduos funcionam como pistas e sinais que podem nos fornecer uma importante chave interpretativa. 0 método abordado por Ginzburg mostra-se de grande utilidade quando aplicado aos contos de Machado no Jornal das Familias, pois, a partir dos três contos analisados, percebemos que os textos, no que tange a referências às vestimentas, contêm esses sinais que auxiliam de maneira significativa na compreensão da narrativa, elucidando a leitura da trama.

\section{Jornal das Familias}

O Jornal das Familias circulou no Brasil entre os anos de 1863 e 1878. Fundado por Baptiste-Louis Garnier, editor francês que veio para o país por volta de 1844, o periódico substituiu outra folha de Garnier, a Revista Popular (1859-1862), que mantinha conteúdos diversos com a finalidade de atender a "todos" os gostos e profissões. 0 intuito da substituição, segundo carta da redação publicada na primeira edição do Jornal das Familias, era fornecer aos leitores assuntos que fossem ao encontro dos anseios da família - "o Jornal das Familias, pois, é a mesma Revista Popular d'ora avante mais exclusivamente dedicada aos interesses domésticos das famílias brasileiras" (AOS NOSSOS..., 1863, p. 2).

No entanto, por conta das temáticas que apresentava, o periódico acabou sendo caracterizado como um veículo destinado principalmente às mulheres. Anos mais tarde, outra carta da redação deixa claro a quem o jornal se dirige: "Minhas senhoras. - O Jornal das Familias tem a subida honra de se dirigir a VV. EEx" (ÀS NOSSAS..., 1869, p. 37). Soma-se a isso o fato de o periódico trazer, durante todos os anos de sua existência, a figura de uma mulher em sua capa (figura 1), além de diversas ilustrações que retratavam mulheres em atividades variadas, corroborando a interlocução feminina. 


\section{JORNAL \\ DAS FAMILIAS \\ PubLICAÇÃO ILLUSTRADA}

RECREATIVA, ARTISTICA, ETC.

\section{ANNO DE 1875}

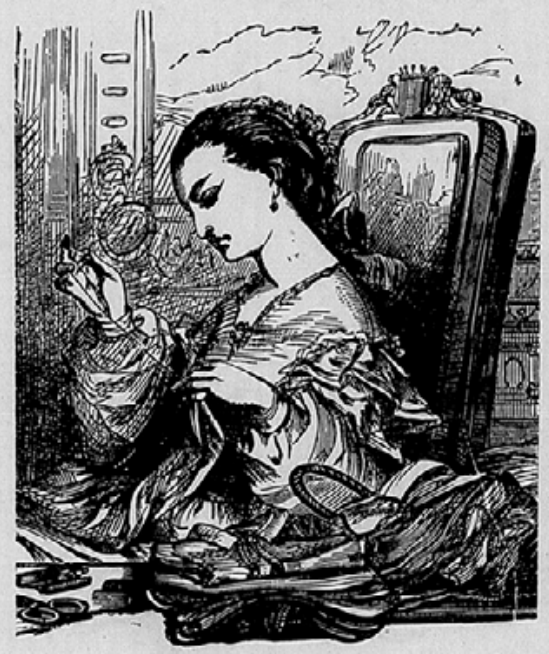

RIO DE JANEIRO

B. L. GARNIER, EDITOR-LIVREIRO

65 , RUA DO OUVIDOR, 65

FONTE: Jornal das Familias. Rio de Janeiro: B. L. Garnier, jan. 1875, n.p. Disponível em: http://memoria. bn.br/DocReader/339776/4338. Acesso em: 2 jul. 2019. Imagem obtida mediante download de arquivo. 
Com periodicidade mensal ${ }^{4}$, o Jornal possuía em torno de 32 páginas por edição e era composto por, citando os gêneros de maior destaque, artigos de moda, economia doméstica e culinária, bem como partituras de piano, conteúdos que, à época, eram considerados quase que exclusivamente pertencentes ao universo feminino. Além disso, era dedicado um espaço expressivo para a literatura, o que, como alega Alexandra Santos Pinheiro (2007), servia para o entretenimento e para a instrução moral das leitoras, visto que o Jornal das Familias era um periódico de cunho conservador 5 . "O tom religioso e moralizador foi marcante. Talvez por causa da presença de padres assinando seções fixas, ou mesmo devido ao pensamento de alguns em educar a parcela de leitoras a quem aqueles escritos eram dedicados" (PINHEIRO, 2007, p. 3). Ainda citando a mesma autora, as narrativas eram compostas, em sua maioria, por "personagens femininas premiadas por seguirem as normas e punidas por transgredi-las" (PINHEIRO, 2004, p. 115).

O que também pode ter influenciado na escolha do tipo de texto literário a ser publicado é o fato de que as mulheres dificilmente possuíam autonomia para eleger suas próprias leituras. Tal situação era causada tanto pela imposta submissão ao homem da casa quanto pela falta de poder aquisitivo, visto que, no século XIX, o número de profissões que as mulheres podiam exercer era muito limitado (modista e professora, por exemplo) e desempenhar qualquer uma delas denotava queda na hierarquia social. Em $O$ espírito das roupas, Gilda de Mello e Souza trata da questão do trabalho feminino, argumentando que "dedicando-se ao trabalho remunerado descia imediatamente de classe. Fora dos trabalhos de agulha, o ensino particular era a única oportunidade de que dispunha uma mulher de certo nascimento para ganhar a vida"6 (SOUZA, 1987, p. 91).

Desse modo, o conteúdo do Jornal das Familias precisava ser aprovado pelos pais ou maridos, pois era necessário que esse conteúdo atendesse ao que os homens desejavam para a educação das mulheres, desejo esse que era, em linhas gerais, o de que elas fossem filhas, esposas e mães dedicadas, zelosas e prendadas. Podemos inferir, portanto, que a recreação e a instrução moral pautavam a linha editorial do Jornal. Por outro lado, é possível identificar fissuras nesse suposto projeto editorial, pois, como alude Pinheiro, "o seu público participa, a partir das narrativas, de discussões que vão além da questão da moral feminina" (PINHEIR0, 2007, p. 77), o que pode ser exemplificado via temáticas como a nacionalidade e o fazer literário. Talvez seja possível apontar que as mudanças de costumes provocavam

\footnotetext{
${ }^{4}$ No ano de 1871, a publicação do Jornal foi interrompida de abril a setembro. Quando o periódico voltou a circular, não foi encontrada qualquer justificativa para a suspensão da publicação no período.

Salientamos que o posicionamento do veículo era conservador do ponto de vista burguês, pois, se partirmos da ótica patriarcal, notamos, ao menos, uma flexibilização no que concerne à possibilidade feminina de obter divertimento e conhecimento.

Quanto às classes mais remediadas, ainda restava à mulher a opção do trabalho de governanta, profissão que, apesar de ser comum na Europa, era um serviço pouco utilizado no Brasil. No que se refere às parcelas mais pobres da população, as mulheres poderiam exercer outros tipos de atividade, como no caso das lavadeiras, por exemplo.
} 
novos problemas sociais que atravessavam a vida cotidiana. Exemplificados pela moda, cujo valor passa pela novidade e pela ruptura com o passado, novos hábitos precisavam de um discurso regulador e de uma narrativa que desse sentido para uma nova configuração do cotidiano. A novidade, no entanto, precisava ser enquadrada na manutenção da ordem patriarcal-burguesa.

No que diz respeito ao seu aspecto material, a folha era impressa na tipografia dos irmãos de Garnier em Paris, circunstância provavelmente motivada por três razões iniciais. Em primeiro lugar, era mais vantajoso economicamente, pois o preço da impressão era mais barato em comparação ao cobrado no Rio de Janeiro. Em segundo, por conta de as tipografias da França serem mais desenvolvidas, e isso lhe proporcionaria uma maior qualidade, o que é comprovado pelo alto padrão das páginas do Jornal das Familias. Por último, pela conveniência de os negócios serem mantidos em família e no país de origem do editor.

Outro ponto que também pode ter feito diferença no momento da escolha do local no qual o Jornal seria produzido é a influência que a França exercia sobre o Brasil no século XIX. Em 1808, com a vinda da família real portuguesa para o Rio de Janeiro, o comércio estrangeiro, que anteriormente era proibido, passa a ser praticado no país, o que permite, mais tarde, a entrada de produtos franceses pelos portos, tais como roupas e livros. De acordo com Luiz Felipe de Alencastro (2011), a grande quantidade de estrangeiros no país após a mudança da Corte para o Brasil (como viajantes e comerciantes) fez com que se formasse no Rio de Janeiro "um mercado de hábitos de consumo relativamente europeizados" (ALENCASTRO, 2011, p. 36).

Em 1822, com a Proclamação da Independência, houve, como afirma Geanneti Tavares Salomon, "um repúdio a tudo que tivesse influência portuguesa" (SALOMON, 2010, p. 71); assim, as famílias abastadas, em vez de enviarem seus filhos para estudar em Coimbra, mandavam-nos para a França, a literatura consumida era, preferencialmente, a de autores franceses, dentre outros sintomas. Então, é patente que um jornal que viesse do país europeu obteria mais prestígio e conseguiria atingir um número maior de leitores. Acrescenta-se o dado de que Paris era a cidade da moda, local onde estavam situadas as melhores maisons e os mais renomados costureiros especializados em trajes femininos ${ }^{7}$; logo, para um periódico que tinha a questão da vestimenta como um dos seus pilares, era vantajoso que suas páginas fossem impressas na capital francesa.

Um ângulo importante a ser analisado ao se estudar o Jornal das Familias é o do seu público leitor, que, como argumenta Pinheiro, era bastante restrito.

\footnotetext{
Um ícone nesse quesito foi Charles Frederic Worth, costureiro inglês residente em Paris que iniciou o costume de desenhar coleções. Ele é reconhecido como o instituidor da alta-costura, "que a partir de então colocará ordem na diversidade, na anarquia do gosto que prevalecia nas massas, reerguendo fronteiras, não mais entre aristocracia e o povo, mas entre os que dominavam uma 'cultura estética' e os que não dominavam" (RODRIGUES, 2010, p. 126).
} 
O jornal [...] circula entre um público restrito de leitores, ou seja, somente entre aqueles que podem pagar por uma assinatura, pois, embora seja vendido de forma avulsa, a estrutura fragmentada de muitos de seus artigos e até mesmo as inúmeras narrativas em folhetim são incentivos para que o público procure por ele, seja adquirindo-o por meio da assinatura anual ou seja consultando-o nas bibliotecas, nos gabinetes de leitura e na casa de amigos. (PINHEIRO, 2007, p. 62)

O número avulso do Jornal das Familias era vendido por mil réis $(1 \$ 000)$, ao passo que a assinatura anual custava dez mil réis $(10 \$ 000)$ para a Corte e Niterói e, para as províncias, 12 mil réis $(12 \$ 000)$. Ao fazer a assinatura, tinha-se direito, no fim de um ano, a um livro de 384 páginas com o conteúdo veiculado; todavia, o custo da encadernação deveria ser pago à parte. É difícil mensurar quanto esses valores representavam no custo de vida da época, mas, se olharmos os anúncios de jornais coetâneos, podemos ter uma ideia de qual era o valor de mercado do periódico quando comparado a outros produtos. Na edição do dia 19 de agosto de 1875 da Gazeta de Noticias, por exemplo, vemos que por $10 \$ 000$ era possível comprar $200 \mathrm{~kg}$ de carvão. Uma comparação mais aproximada, como expõe Alexandra Pinheiro, é o valor do livro de poemas Crisálidas, de Machado de Assis, que custava $1 \$ 500^{8}$; ou seja, para adquirir o volume completo do Jornal das Familias era necessário desembolsar um valor superior a seis vezes o preço do livro de Machado.

Ainda atentando para o público leitor, salientamos que, conforme o censo de 1872, menos de $16 \%$ da população do Império era alfabetizada, e mesmo que a taxa alcançasse os $36 \%{ }^{9}$ da Corte, o índice ainda era muito baixo. A partir disso, depreendemos que, majoritariamente, o periódico era consumido por pessoas da elite ou de classe mediana (como gerentes e comerciantes ricos, por exemplo), pois, por mais que fosse possível lê-lo por meios que não fossem a compra - como empréstimos -, o acesso à palavra escrita era bastante limitado. Contudo, seus dezesseis anos de duração indicam uma boa recepção. 0 que também pode ter contribuído para sua longevidade é o fato de o Jornal das Familias contar com correspondentes que distribuíam exemplares em cidades mais afastadas da Corte e no exterior.

Ao examinarmos o público-alvo do Jornal e o conteúdo que era oferecido, notamos qual era a imagem que a sociedade tinha em relação às demandas femininas e o que ela esperava que essas demandas fossem. Política, por exemplo, não era um assunto referido, pois, possivelmente, era visto como um tópico que só interessava aos homens. Ao escrever

\footnotetext{
${ }^{8}$ Conforme dados do projeto Memória de Leitura, coordenado pelas professoras Márcia Abreu e Marisa Lajolo. Disponível em: http://www.unicamp.br/iel/memoria/base_temporal/Numeros/index.htm. Acesso em: 2 jul. 2019.

9 Conforme dados recolhidos pelo censo de 1872, constantes no catálogo da biblioteca do IBGE. Disponível em: https://biblioteca.ibge.gov.br/biblioteca-catalogo?view=detalhes\&id=225477. Acesso em: 2 jul. 2019.
} 
sobre o Jornal das Familias na série Ao acaso - folhetim semanal publicado no Diário do Rio de Janeiro -, Machado de Assis faz a seguinte observação:

Não deixarei de recomendar aos leitores fluminenses [...] o Jornal das Familias, verdadeiro jornal para senhoras, pela escolha do gênero de escritos originais que publica e pelas novidades de modas, músicas, desenhos, bordados, esses mil nadas tão necessários ao reino do bom tom. (MACHADO DE ASSIS, 1865, p. 1, grifo nosso)

Como vemos, às senhoras cabem leituras acerca de "mil nadas" que, objetivamente, só são necessários ao "reino do bom tom", mas que não auxiliam em reflexões mais profundas ou na emancipação feminina. Vale reparar, inclusive, que as palavras de Machado circunscrevem a vida da mulher ao reino doméstico, visto que não são mencionadas possibilidades de atividades públicas.

Quanto à estrutura, o Jornal das Familias era dividido em seções, sendo algumas delas "Economia doméstica”, "Medicina doméstica" e "Mosaicos" (que abarcava assuntos diversos, como ensinamentos religiosos). As seções de maior prestígio e estabilidade eram "Romances e novelas", "Poesia" e "Moda”, esta última costumava fechar as edições do periódico, trazendo imagens de figurinos parisienses e ensinamentos de confecção, o que não significava que as leitoras deveriam costurar os modelos, mas sim enviar os moldes para a modista.

No que concerne às seções literárias, o Jornal das Familias contava com diversos colaboradores, sendo os mais reconhecidos atualmente Joaquim Manuel de Macedo e Machado de Assis. Abordando especificamente "Romances e novelas", tratava-se da seção que abria o periódico, o que já demonstra sua relevância, além de, em seus dezesseis anos de circulação, o Jornal ter publicado 223 narrativas. Nessa seção, Machado de Assis destaca-se como o escritor mais assíduo, tendo publicado aproximadamente 85 contos entre 1864 e $1878^{10}$, com exclusão do ano de 1867. Em alguns momentos, Machado chegou a contar com três textos de sua autoria na mesma edição, textos esses que, muitas vezes, eram assinados por pseudônimos, como J.J, Job, Victor de Paula e Lara. Tal como ocorria com as demais narrativas do Jornal, os contos de Machado normalmente eram publicados em mais de uma edição, de forma seriada.

Ao abordar os contos produzidos por Machado nos anos de 1860 e 1870, Alfredo Bosi, em A máscara e a fenda, afirma que são "histórias presas às convenções do romantismo urbanizado da segunda metade do século XIX" (BOSI, 2007, p. 75) e que não são tão refinadas esteticamente quanto as escritas posteriormente; porém, devem, igualmente, ser objeto de análise ao estudarmos a produção contística do autor.

\footnotetext{
${ }^{10}$ Por conta dos vários pseudônimos utilizados por Machado, é difícil definir exatamente o número de contos escritos por ele no Jornal das Familias.
} 
Quem faz uma antologia prefere excluir a maioria dessas últimas, sem dúvida menos sugestivas esteticamente; mas o analista não pode omitir o fato: Machado foi também um escritor afeito às práticas de estilo das revistas familiares do tempo, principalmente nas décadas de 1860 e 70.0 jovem contista exercia-se na convenção estilística das leitoras de folhetins, em que os chavões idealizantes mascaravam uma conduta de classe perfeitamente utilitária. (BOSI, 2007, p. 75) 11 $^{11}$

Partindo do argumento de Bosi, podemos inferir que Machado adequava suas narrativas à proposta do suporte no qual estava publicando; no caso do Jornal das Familias, essa adequação consistiria em textos de cunho moralizante, que primassem pela educação e pelo divertimento das leitoras. Ao examinar os contos, percebemos que essa hipótese se confirma em diversos casos, pois boa parte dos enredos gira em torno de histórias de amor em que, por meio da protagonista (sublinhando que normalmente as personagens femininas estão em maior destaque), é passado algum ensinamento para as leitoras.

No entanto, também encontramos contos em que há um tensionamento entre enredo e linha editorial do jornal, uma vez que o desfecho da história não se enquadra no que seria esperado pelos "bons costumes". Por conta do suposto menor refinamento estético, muitas vezes os contos escritos nos anos de 1860 e 1870 são vistos como narrativas de baixa qualidade, e as análises acabam por não contemplar esse tensionamento. Um exemplo de desencontro entre linha editorial e enredo está no conto "Aires e Vergueiro", publicado em janeiro de 1871 e assinado pelo pseudônimo J.J., no qual Carlota, esposa de Vergueiro, envolve-se com o sócio e amigo do marido, Aires, e, em vez de receber algum tipo de punição (como ficar sozinha, sem a companhia de Aires ou de Vergueiro), foge com o amante para desfrutar a vida na Europa.

\section{Pela aparência se enxerga a essência: as roupas revelam a subjetividade}

O conto "Brincar com fogo", assinado pelo pseudônimo Lara e publicado nos meses de julho e agosto de 1875, traz em seu enredo a história de duas amigas - Mariquinhas e Lúcia - cortejadas pelo mesmo rapaz, João dos Passos. Inicialmente, as duas moças (18 e 19 anos, respectivamente) divertem-se com a situação, uma mostrando à outra as cartas recebidas e denunciando o número de vezes que o moço passava em frente às suas casas. Entretanto, com o transcorrer do tempo, a brincadeira perde a graça, e as meninas mentem que João dos Passos cessou o contato com elas, uma acreditando na farsa da outra. Dessa forma, o petimetre ${ }^{12}$ (como é denominado pelo narrador) inicia um namoro com as duas garotas, o que desperta desejo de

\footnotetext{
${ }^{11} \mathrm{Em}$ Os contos de Machado de Assis: o machete e o violoncelo, John Gledson apresenta uma linha de argumentação semelhante.

${ }^{12}$ Indivíduo elegante, janota.
} 
matrimônio tanto em Mariquinhas quanto em Lúcia. Sem saber com qual das duas casar, João dos Passos pede, por meio de cartas, alguns dias de espera para as pretendentes, alegando compromissos profissionais. Por engano do mensageiro, Mariquinhas e Lúcia recebem a correspondência trocada e acabam descobrindo o segredo de João dos Passos e, consequentemente, da amiga. Elas não falam mais com o rapaz que, por sua vez, sem saber que havia sido descoberto, decide se casar com uma prima por causa dos bens que ela possuía. No fim, temos a notícia de que Mariquinhas e Lúcia casam algum tempo depois, mas nunca reataram a amizade.

O que interessa mais precisamente para a análise proposta é a caracterização que o narrador faz de João dos Passos.

\footnotetext{
Recebera do alfaiate a primeira calça da última moda, fazenda finíssima, e comprara na antevéspera um chapéu fabricado em Paris. Estava no trinque. Tinha certeza de causar sensação. Era João dos Passos um rapaz de vinte e tantos anos, estatura regular, bigode raro e barba rapada. Não era bonito nem feio; era assim. Tinha alguma elegância natural, que ele exagerava com uns meneios e jeito que dava ao corpo na ideia de que ficaria melhor. Era ilusão, porque ficava péssimo. (MACHADO DE ASSIS, 1875a, p. 211, grifos nossos)
}

O rapaz possui - ou busca se apropriar dos - atributos de um dândi, homem do século XIX, normalmente proveniente da burguesia, que tinha uma extrema preocupação com a aparência. Segundo Baudelaire (2009), esse indivíduo tem a elegância como profissão, pois é rico e dedicado ao ócio, e a toalete perfeita é a maneira de atestar a superioridade de seu espírito: é uma forma de distinção ${ }^{13}$. No caso de João dos Passos, a quem não dava "muito o emprego que tinha na Casa de Misericórdia" (MACHADO DE ASSIS, 1875b, p. 233), a adesão à moda e aos gestos a ela ligados poderiam fazer parte da encenação para conseguir um casamento vantajoso, o que alcança, finalmente, ao unir-se a "uma prima com belos olhos e cinco prédios" (MACHADO DE ASSIS, 1875b, p. 240).

No Brasil, o termo empregado para designar o homem retratado por Baudelaire era janota; contudo, os hábitos de ambas as categorias não eram exatamente os mesmos, porque, enquanto os janotas trajavam itens um tanto espalhafatosos, o dândi pregava a limpeza do visual. Na apresentação de João dos Passos, vemos que esse exagero vai para além das roupas, dado que suas maneiras são igualmente excessivas. Cabe ressaltar que, por conta da veemente dedicação à aparência, a imagem do dândi era relacionada a um estilo de vida superficial e muitas vezes leviano. Abaixo, colocamos a figura de como (supostamente ${ }^{14}$ ) seria João dos Passos (figura 2), imagem publicada junto ao conto em julho de 1875.

\footnotetext{
${ }^{13}$ São símbolos do dandismo Beau Brummel (1778-1840) e Oscar Wilde (1854-1900).

${ }^{14}$ Supostamente porque, apesar de as narrativas do Jornal das Familias serem normalmente acompanhadas de alguma ilustração, nem sempre as imagens tinham relação com o enredo. No caso de "Brincar com fogo", dada a caracterização de João dos Passos, parece que a ideia foi estabelecer uma conexão entre texto e ilustração.
} 
FIGURA 2 - JANOTA

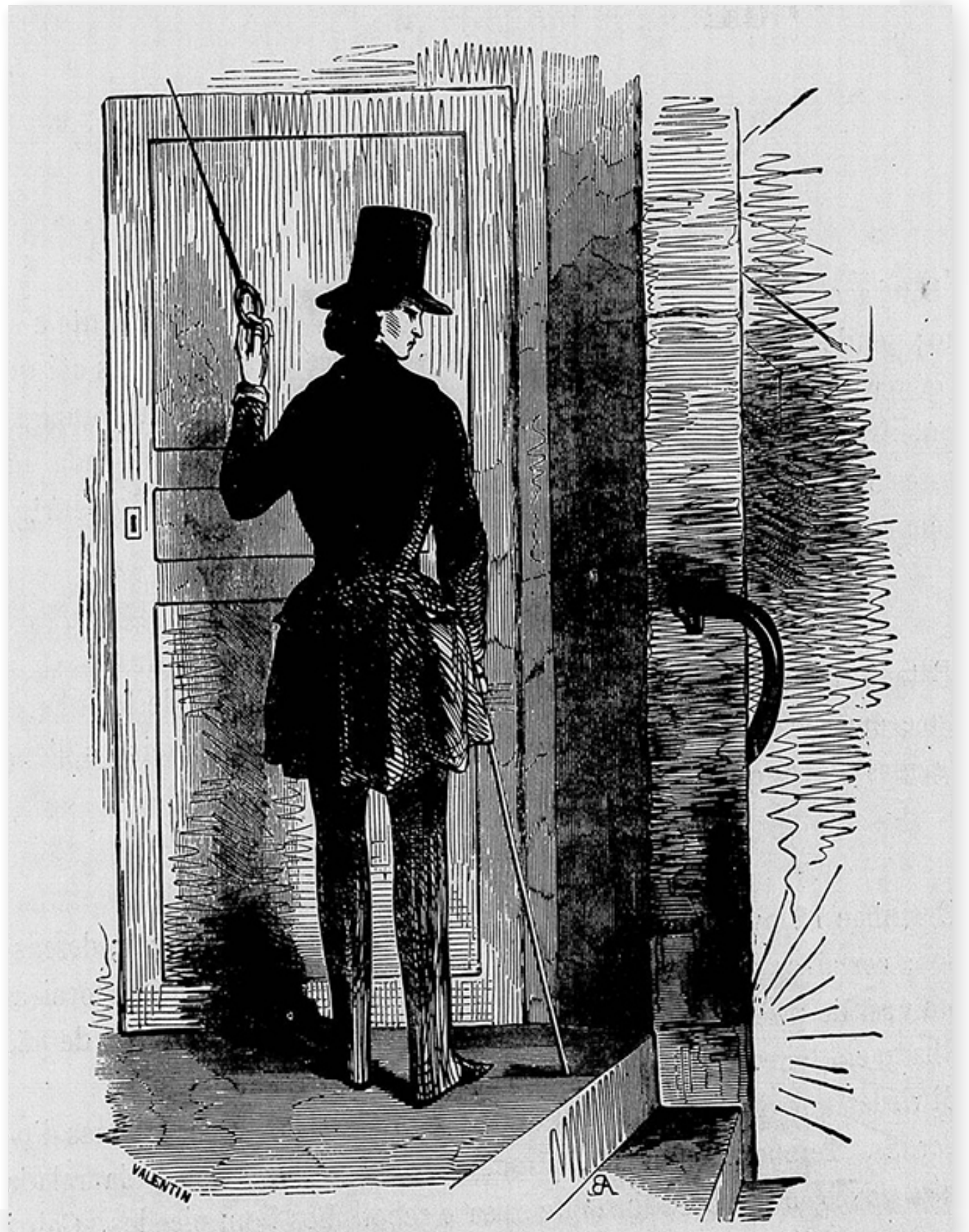

FONTE: Jornal das Familias. Rio de Janeiro: B. L. Garnier, jul. 1875, p. 215. Disponível em: http://memoria. bn.br/DocReader/339776/4533. Acesso em: 2 jul. 2019. Imagem obtida mediante download de arquivo. 
Tomando como pressupostos a conjuntura de o Jornal das Familias ter como uma de suas bases os artigos de moda (pois, mesmo a folha não explorando a moda masculina, suas leitoras supostamente possuíam uma sensibilidade para o tema) e de que, tanto por uma questão financeira quanto pelo alto índice de analfabetismo, era uma pequena parcela elitizada do país que tinha acesso ao periódico, acreditamos que as interlocutoras estavam familiarizadas com o tipo de homem descrito - e, de certa forma, caricaturado - no conto. Em vista disso, os detalhes relacionados aos trajes, que podem passar por mero preciosismo, têm um papel fundamental na construção do perfil da personagem.

À medida que o enredo vai se desenvolvendo, João dos Passos apresenta uma conduta cada vez mais duvidosa aos olhos do leitor, o que se confirma no fim do conto, quando o rapaz se casa com a prima por interesses materiais. Essa índole oportunista, então, já havia sido sinalizada no início da narrativa, momento em que a aparência do rapaz foi revelada. Aqui, mobilizamos o argumento de Geanneti Salomon relativo a Dom Casmurro para pensar "Brincar com fogo", pois creio que, nesse caso, em ambos os textos, a indumentária está cumprindo função análoga.

O leitor quase não percebe estar construindo a imagem de Capitu também por seu descritivo. A indumentária é utilizada na obra sem detalhamentos desnecessários que visam somente a adornar a narrativa, mas esta vem carregada de indícios de quem a está vestindo, agregando à personagem características que virão a beneficiar as estratégias narrativas do autor. (SALOMON, 2010, p. 49)

No ensaio Narrar ou descrever?, György Lukács (2010) caracteriza a descrição como um expediente formal necessário para dar conta da complexidade crescente do vínculo entre indivíduo e classe a partir do século XIX. Desse modo, conforme a análise da obra de Balzac empreendida pelo autor, "a descrição exata da pensão Vauquer, com sua sujeira, seus odores, seus alimentos, sua criadagem, é absolutamente necessária para tornar inteiramente compreensível o tipo particular de aventureiro que é Rastignac" (LUKÁCS, 2010, p. 156). Portanto, a descrição passa a se fazer necessária como suporte para a representação da realidade social e dos caracteres, desde que não se torne o princípio composicional ao ser hipertrofiada, como se daria no caso de Zola ou Flaubert, escritores criticados por Lukács. Sem entrar no mérito da avaliação que Lukács faz de Flaubert, ele chama atenção para a dimensão moderna da descrição na prosa ficcional do século XIX e de como os detalhes apresentados passam a compor a narrativa para que ele se enraíze no cotidiano burguês, social e historicamente representado.

Machado de Assis, contemporâneo do desenvolvimento do realismo, também criticou quando o exagero levou a descrição a ganhar autonomia em relação ao enredo. No dia 16 de abril de 1878, sob o pseudônimo de Eleazar, o autor publicou no jornal fluminense $O$ Cruzeiro uma crítica ao romance $O$ primo Basílio, de Eça de Queirós. No texto, Machado critica a filiação do autor português à escola realista, declarando de maneira irônica que "a nova 
poética [...] só chegará à perfeição no dia em que nos disser o número exato dos fios de que se compõe um lenço de cambraia ou um esfregão de cozinha" (MACHADO DE ASSIS, 1878, p. 1). Verificamos em sua crítica que Machado via a ênfase na descrição como uma diluição da hierarquia na composição, visto que o descritivismo alinha em um mesmo plano sujeitos e objetos, o que acaba por minimizar a importância dos primeiros.

Em “Brincar com fogo", publicado três anos antes da crítica ao $O$ primo Basílio, a descrição é um artifício formal importante para a composição, mas subordinado à construção de caracteres e ao desenvolvimento da narrativa. Ao mencionar que João dos Passos "recebera do alfaiate a primeira calça da última moda, fazenda finíssima, e comprara na antevéspera um chapéu fabricado em Paris" (MACHADO DE ASSIS, 1875a, p. 211), por exemplo, o narrador apresenta a exterioridade da personagem em intrincada relação com sua índole, ativando conhecimentos de moda que reconhecia explícitos na situação de interlocução em que estava inserido, não configurando nenhuma prodigalidade descritiva, tanto é que a frivolidade da personagem se comprova no fim da narrativa.

A natureza tinha-lhe dado uma vista agudíssima; a imitação deu-lhe uma luneta de um vidro só, que ele trazia pendente de uma fita larga ao pescoço. [...] João dos Passos aproximava-se. Vinha pela calçada oposta, com luneta assestada na janela em que as duas moças estavam. Quando viu que não eram desagradáveis, antes mui simpáticas e galantes, aperfeiçoou o jeitinho que dava ao corpo e entrou a fazer com a bengala de junco passagens difíceis e divertidas. (MACHADO DE ASSIS, 1875a, p. 211, grifos nossos)

Na composição de João dos Passos, o narrador constrói a oposição entre natureza e imitação. A segunda faz do petimetre uma figura cômica. Assim, a luneta não serve para ver, mas para ser visto. A bengala é um instrumento para fazer malabarismos que agradem as moças. Além desses, no fim de sua galanteria, ele usa o lenço para uma despedida disfarçada. A questão central é os objetos da moda virem acompanhados de um discurso valorativo que coloca em dois campos distintos aquilo que se adéqua à natureza do sujeito e aquilo que, artificial, restringe-se à imitação que esconde e disfarça a identidade do usuário. No caso, o funcionário da Misericórdia faz questão de se passar por um despreocupado dândi. Há, então, um movimento duplo do descrever a figura nesse caso: ao passo que a descrição especifica e individualiza a personagem, ela transcende ao apresentar um tipo social supostamente reconhecido pelo seu público leitor.

Já os comentários do narrador acerca da aparência de João dos Passos ("estava no trinque", "não era bonito nem feio; era assim", "era ilusão, porque ficava péssimo" (MACHADO DE ASSIS, 1875a, p. 211)), que interferem no relato de maneira cômica, exprimem desaprovação a esse tipo de conduta. De certa forma, há uma lição a ser ensinada, as leitoras precisam aprender a perceber os sinais para não se envolverem com rapazes desse tipo, que 
se vestem de tal modo com a finalidade de atrair os olhares das moças. 0 próprio título do conto ("Brincar com Fogo") já sugere que a leitora encontrará um ensinamento, uma instrução, um exemplo a não ser seguido.

No texto $O$ narrador: considerações sobre a obra de Nicolai Lescov, Walter Benjamin (2012) aponta que a verdadeira narrativa sempre traz consigo uma utilidade, que pode ser uma norma de vida, uma sugestão prática ou um ensinamento moral. Contudo, por conta do advento da imprensa e do estilo de vida vigente na modernidade, esse tipo de narrativa, relacionada à tradição oral, acaba por ser perder, sendo a short story uma forma de o homem moderno abreviar a narrativa. Assim sendo, o narrador de "Brincar com fogo" está inserido nessa nova configuração social, pois sua história tem uma forma moderna, que não se vale mais da palavra falada ou da gestualidade como maneira de transmissão. Ademais, está subordinado a um veículo de comunicação, tendo impossibilitado o contato direto com o interlocutor e a troca de experiências provenientes desse contato. Igualmente, a narrativa possui restrições de ordem temática e de extensão, por exemplo, além de estar a serviço do tom moralizante do Jornal das Familias, cumprindo um papel comercial.

Entretanto, "Brincar com fogo" ainda possui resíduos dessa maneira antiga de contar, na qual um narrador conselheiro visa passar algum tipo de sabedoria para seu interlocutor. Para tanto, a representação da moda assume papel significativo para o que parecem ser os objetivos do narrador do conto, porque consegue atender aos interesses do Jornal das Familias (e, por consequência, daquela sociedade que via na mulher um ser que necessitava de tutela) ao mesmo tempo que, em alguma medida, cumpre com as atribuições do narrador tradicional, empregando a descrição do vestuário como mais um meio de emitir conhecimento.

Já no conto "Encher tempo", publicado de abril a julho de 1876 e com Machado de Assis assinando com seu próprio nome, temos a seguinte descrição da personagem Lulu:

Os cabelos, penteados em bandós, iam juntar-se atrás da cabeça e caíam em duas tranças finas, atadas na ponta por laços de fita azul. Azul era a cor do cinto que trazia destacando sobre o branco do vestido de cassa, cortado e trabalhado com extrema simplicidade. Nenhum enfeite mais; e quadrava-lhe tanto aquela ausência de adornos, que parece lhe destoaria o menor deles que se lembrasse de pôr. (MACHADO DE ASSIS, 1876, p. 115)

A primeira característica relacionada à aparência de Lulu é o cabelo em bandós, penteado muito comum no século XIX que consistia em deixar o cabelo repartido ao meio e esticado para os lados da cabeça, cobrindo as orelhas e sendo preso atrás. Na seção "Modas" encontramos várias referências a esse tipo de penteado, tanto para a adoção em bailes quanto para o visual cotidiano. Então, podemos observar, logo no início da descrição, um diálogo com outras seções do periódico e, consequentemente, com as interlocutoras. 
Sobre o restante do perfil, notamos que Lulu se traja de maneira modesta, sem roupas ou adornos caros e/ou vistosos. Considerando que ela mora com seu tio, o padre Sá, e que o tom religioso perpassava pelo Jornal das Familias, uma interpretação possível é a de a simplicidade das vestes de Lulu ser uma forma de demonstrar, por meio do texto literário, como os ensinamentos encontrados no periódico deveriam ser colocados em prática. Essa percepção é validada no parágrafo subsequente à descrição das roupas de Lulu, no qual o narrador faz a seguinte colocação:

O padre Sá admirou durante alguns instantes a sobrinha, não ostensivamente, mas à socapa, com uma reserva e discrição, cujo sentido era fácil de adivinhar. Ele não queria acordar-lhe o sentimento da vaidade, que faria desmerecer-lhe a natural beleza, cujo maior encanto era ser inconsciente e singela. Além disso, e antes disso, a alma vaidosa ficaria mais perto do pecado; e o padre Sá tinha posto todo o seu zelo em educar aquela alma na prática das virtudes cristãs. (MACHADO DE ASSIS, 1876, p. 115)

A descrição de Lulu parece anunciar uma pureza virginal, antípoda do artifício e da imitação. Tal como ocorre em "Brincar com fogo", em "Encher tempo" o detalhamento das roupas tem forte ligação com o comportamento que a personagem adota durante a narrativa. Lulu é uma menina meiga, discreta e tímida, traços de personalidade que não combinariam com trajes chamativos. É igualmente significativo o fato de Lulu estar de vestido branco, visto que, no século XIX, o uso dessa cor atestava a inocência das moças; conforme Mariana Rodrigues, por intermédio do vestido branco as "donzelas anunciavam seu meigo pudor virginal, a inocência ignorante" (RODRIGUES, 2010, p. 86). Além do branco, o azul, cor da fita que adornava os cabelos e do cinto do vestido, também denotava pureza; segundo Rodrigues, "para não correr riscos ou dar margens a especulações, para as mocinhas definitivamente somente as três cores [branco, azul e róseo]” (RODRIGUES, 2010, p. 84).

A inocência anunciada pela descrição das vestes é comprovada com o decorrer da trama, pois a personagem não atenta que Pedro, rapaz que frequentava sua casa para ter lições religiosas com seu tio, estava apaixonado por ela. À vista disso, Lulu mostra-se o oposto de João dos Passos: ela possui um caráter reto, moral (segundo os parâmetros do Jornal das Familias), o que não comportaria uma preocupação demasiada com a exterioridade. A escolha de seus trajes aparece no conto como uma virtude, reforçando a linearidade entre indumentária e personalidade.

No entanto, se olharmos os figurinos presentes no Jornal das Familias, notamos uma contradição no que concerne ao discurso e às descrições e imagens de moda. Em abril de 1876, data da publicação da primeira parte do conto "Encher tempo", encontramos a seguinte imagem, acompanhada pela descrição dos trajes (figuras 3 e 4). 
FIGURA 3 - FIGURINO DE MODAS

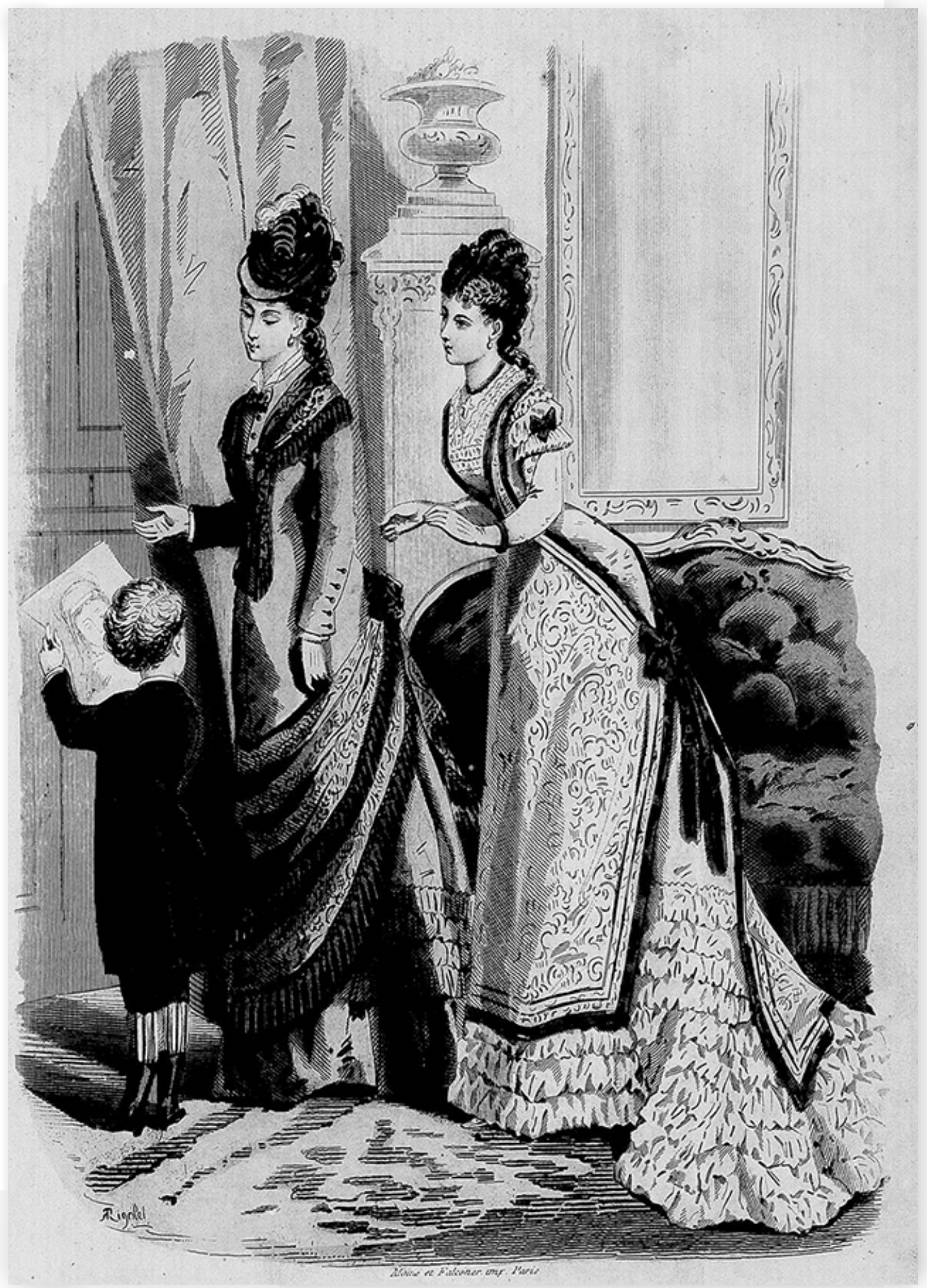

FONTE: Jornal das Familias. Rio de Janeiro: B. L. Garnier, abr. 1876, n.p. Disponível em: http://memoria. bn.br/DocReader/339776/4842. Acesso em: 2 jul. 2019. Imagem obtida mediante download de arquivo. 


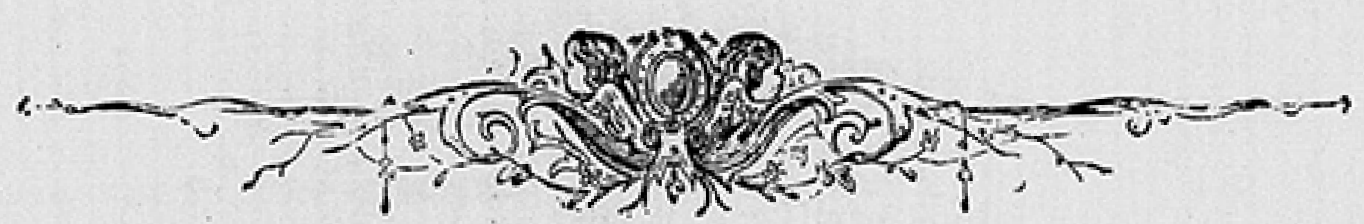

\section{MODAS.}

\section{DESGRIPC̣̃̃O DO FIGURINO DE MODAS.}

Primeiro vestuario. - Trajo de veludo roxo para menino. Paletó apertado na cintura. Calças curtas de veludo roxo.

Segundo vestuario. - Trajo de faille cinzento para passeio. Saia de faille cinzenta guarnecida com um folho franzído, um macheado e fofos. Manta de adamascado cinzento, guarnècida com um franjado. Chapéo de feltro cinzento, torcal de faille e setim da mesma côr preso por um ornato dourado; pluma branca comprida e ra malhete de rosas.

Terceiro vestuario para baile. - Saia de filó branco guarnecida com fofos. Tunica de adamascado branco aberta sobre o lado, guarnecida com galões e borlas de ouro. Galão de ouro nos cabellos.

FONTE: Jornal das Familias. Rio de Janeiro: B. L. Garnier, abr. 1876, p. 124. Disponível em: http://memoria. bn.br/DocReader/339776/4864. Acesso em: 2 jul. 2019. Imagem obtida mediante download de arquivo. 
É possível constatar que nenhum dos vestuários é pautado pela simplicidade; mesmo a roupa de passeio, que não pediria o glamour do traje de baile, é repleta de detalhes e ornamentos que exteriorizam o comportamento vaidoso condenado pela personagem padre Sá. Esse contrassenso indica que, apesar do que pregava a linha editorial, o Jornal das Familias estava inserido em uma lógica de mercado, e, sendo um periódico que se propunha a apresentar sugestões de vestimentas, não poderia deixar de explorar o que estava na moda.

Se repararmos na figura 3, encontramos símbolos religiosos - o pingente em formato de cruz no pescoço da mulher à direita e, ao que parece, uma santa desenhada pelo menino -, o que manifesta o esforço dos editores para espalhar pelo periódico uma mensagem religiosa, mas também representa a dificuldade de equilibrar ideologia e demanda mercadológica. Além disso, é possível pensar na ambivalência do crucifixo, pois, ao mesmo tempo que denota religiosidade, é um adorno que atende à vaidade da mulher que pretende parecer sofisticada diante de seus pares. Como é apontado por Roland Barthes (2009), a moda se constrói nas revistas por meio da articulação entre a figura e a legenda explicada. Quando se pensa também nas narrativas como forma de significar os usos da moda, a relação entre os dois termos (imagem e discurso) se realiza como tensão.

Como último exemplo, trazemos a narrativa "Um esqueleto", publicada em outubro e novembro de 1875 e assinada pelo pseudônimo Victor de Paula. Trata-se de um conto emoldurado, em que, na primeira parte, o narrador apresenta a seguinte situação: dez ou 12 rapazes conversam sobre artes, letras e política; em determinado momento, um dos moços, Alberto, fala de dr. Belém, homem com quem teve lições de alemão. Já que os demais convivas não conheciam dr. Belém, Alberto o descreve: "Era um homem extremamente singular. No tempo em que me ensinou alemão usava duma grande casaca que lhe chegava quase aos tornozelos e trazia na cabeça um chapéu-de-chile de abas extremamente largas" (MACHADO DE ASSIS, 1875c, p. 290).

Inicialmente, é notável a circunstância de as roupas estarem em primeiro plano no momento da caracterização, indicando a capacidade que a vestimenta possui de acentuar as particularidades dos indivíduos. A respeito do tipo de traje retratado, é importante marcar que a casaca era, no século XIX, um dos símbolos de elegância masculina; consequentemente, era uma peça obrigatória no guarda-roupa dos homens que desejavam estar elegantes aos olhos da sociedade. Porém, o modelo utilizado por dr. Belém não estava de acordo com o padrão. Marcelo Araújo lembra que a casaca (figura 6) se estenderia "até quase a altura dos joelhos, mas sem recobrir as pernas na parte da frente, conferindo assim à parte de trás da casaca o feitio de uma 'cauda'” (ARAÚJO, 2012, p. 26). 


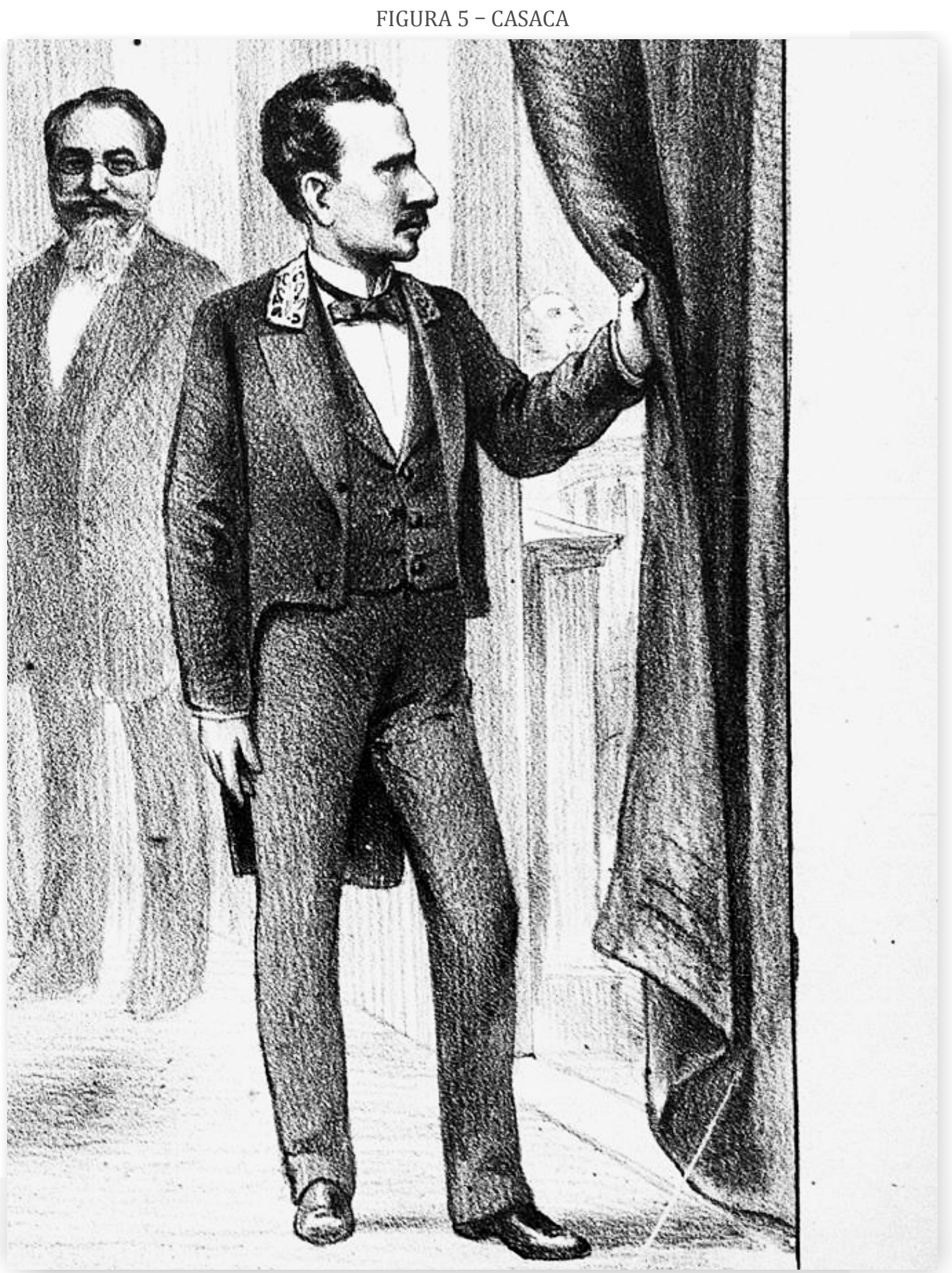

FONTE: Revista Illustrada. Rio de Janeiro, 11 ago. 1888, p. 1. Disponível em: http://memoria.bn.br/ DocReader/332747x/3769. Acesso em: 2 jul. 2019. Imagem obtida mediante download de arquivo. 
Já o chapéu-de-chile é um chapéu de palha requintado, mas que nada tem a ver com a cartola, chapéu emblemático do século XIX.

Diante dessas informações, entendemos a seguinte reação de um dos ouvintes: "Devia ser pitoresco" (MACHADO DE ASSIS, 1875c, p. 290). Esse adjetivo, igualmente com o "singular" dito por Alberto, é corroborado nas próximas quatro partes da trama, nas quais a palavra passa a ser de Alberto (na sexta e última parte a palavra volta para o narrador primário, fechando a moldura), pois dr. Belém mantinha em sua casa, dentro de um armário, o esqueleto da esposa falecida, mulher que ele próprio matara por acreditar que estava sendo traído, desenterrando-a ao descobrir que a suspeita era falsa ${ }^{15}$. Logo, a personalidade "excêntrica" de dr. Belém já havia sido evidenciada no momento em que suas vestes foram descritas.

O constante uso da casaca, que "nunca deixava, salvo quando se recolhia à noite" (MACHADO DE ASSIS, 1875c, p. 293), expressa apego a algo que ele deveria deixar para trás, que já estaria em tempo de se desfazer. Após casar-se pela segunda vez, com d. Marcelina, "o doutor consentiu em vestir-se menos excentricamente (MACHADO DE ASSIS, 1875d, p. 322)". Nesse sentido, há uma ironia sutil no conto de que a moda europeia poderia normalizar a excentricidade do patriarcalismo brasileiro, sua mistura de doçura e violência; contudo, por mais que dr. Belém aceite abandonar a antiga casaca, sua alma permanece cristalizada na figura da morte, da caveira, que diz e reafirma seu direito de matar a esposa por mera suspeição sua, visto que, inclusive, Belém ameaça Marcelina de morte caso ele suspeitasse de alguma traição ${ }^{16}$.

Analisando por esse viés, podemos pensar no Jornal das Familias, apesar de todas as suas características conservadoras, como um veículo que lenta e implicitamente passa a enxergar a mulher como um sujeito detentor de direitos. Então as roupas, além de auxiliarem na construção da personalidade do caractere, podem servir como metáfora para representar a incapacidade de dr. Belém se despir do passado e, talvez, da necessidade de os homens abandonarem o ideal de que a mulher é um ser que pode ser subjugado pelo sexo masculino. Alexandra Pinheiro (2007) afirma que o Jornal das Familias não militava explicitamente pela emancipação feminina, mas que possuía alguns artigos que, para além do divertimento e dos ensinamentos morais, pretendiam instruir as leitoras acerca de temas como geografia e educação formal. Sendo assim, é possível que Machado tenha enxergado a possibilidade de tratar literariamente um assunto delicado como esse no Jornal das Familias, mas, para tanto, o fez de maneira velada e obscura.

\footnotetext{
${ }^{15}$ Inicialmente, a narrativa parece se desenvolver a partir de um dito popular de origem inglesa. Ter um esqueleto no armário significa ter um segredo, algo inconfessável. Porém, enquanto algumas pesquisas indicam que tal expressão data de meados do século XIX (ou seja, poderia ser conhecida por Machado), outras afirmam que seria do início do século XX.

${ }^{16}$ No final do conto, Belém afirma que Alberto e Marcelina estão apaixonados; com isso, decide deixá-los, partindo abraçado ao esqueleto.
} 


\section{Considerações finais: interpretando os índices}

Retomando a discussão acerca do método indiciário proposto por Ginzburg (1989), a análise da descrição do vestuário das personagens evidencia camadas narrativas que, a depender da perspectiva de leitura, podem passar despercebidas. A atenção aos indícios é capaz, pois, de revelar sentidos, ampliar possibilidades de interpretação. Por meio desses indícios (os trajes exagerados de João dos Passos, o vestido simples de Lulu e a singularidade da casaca de dr. Belém), notamos que a composição dos caracteres abarca dados internos e externos que parecem não apresentar contradições. Portanto, a descrição da indumentária colabora para a construção das personagens, atuando como uma pista do que está por vir, operando como um sinal de alerta para o leitor.

Entretanto, se, por um lado, de acordo com os indícios, as personagens parecem não apresentar contradição entre interioridade e exterioridade, observamos, por outro, que, ao articularmos a leitura dos contos analisados neste artigo com uma leitura das demais seções do Jornal das Familias, algumas tensões sobressaem. Embora a linha editorial do periódico se assente, grosso modo, em um discurso moralista orientado pela ideologia católico-patriarcal, as narrativas aqui estudadas incorporam como pressuposto a expectativa de que seu público leitor possuiria conhecimentos de moda, os quais lhes eram fornecidos, em boa medida, pelo próprio periódico. Desse modo, vaidade e religião, moralidade e entretenimento, pares antitéticos à primeira vista, estão entrelaçados no Jornal das Familias e, como pudemos verificar, nas narrativas de Machado de Assis publicadas no periódico.

\section{Referências}

ALENCASTRO, Luiz Felipe de. Vida privada e ordem privada no Império. In: NOVAIS, Fernando; ALENCASTRO, Luiz Felipe de (Orgs.). História da vida privada no Brasil: Império. São Paulo: Companhia das Letras, 1997. (História da vida privada no Brasil, v. 2)

AOS NOSSOS leitores. Jornal das Familias. Rio de Janeiro: B. L. Garnier, jan. 1863, p. 1-2. Disponível em: http://memoria.bn.br/DocReader/339776/1. Acesso em: 2 jul. 2019.

ARAÚJO, Marcelo de. Dom Pedro II e a moda masculina na época vitoriana. São Paulo: Estação das Letras e Cores, 2012.

ÀS NOSSAS leitoras. Jornal das Familias. Rio de Janeiro: B. L. Garnier, fev. 1869, p. 37-38. Disponível em: http://memoria.bn.br/DocReader/339776/2358. Acesso em: 2 jul. 2019.

BARTHES, Roland. Sistema da moda. Trad. Ivone Castilho Benedetti. São Paulo: Editora WMF Martins Fontes, 2009. 
BAUDELAIRE, Charles. 0 dândi. In: BALZAC et al. Manual do dândi: a vida com estilo. Organização, tradução e notas de Tomaz Tadeu. Belo Horizonte: Autêntica Editora, 2009. (Coleção Mimo)

BENJAMIN, Walter. 0 narrador: considerações sobre a obra de Nikolai Leskov. In: BENJAMIN, Walter. Magia e técnica, arte e política: ensaios sobre literatura e história da cultura. 8. ed. revista. Trad. Sérgio Paulo Rouanet. São Paulo: Brasiliense, 2012. (Obras escolhidas, v. 1)

BOSI, Alfredo. A máscara e a fenda. In: BOSI, Alfredo. Machado de Assis: o enigma do olhar. São Paulo: WMF Martins Fontes, 2007.

CALANCA, Daniela. História social da moda. 2. ed. Trad. Renato Ambrosio. São Paulo: Editora Senac São Paulo, 2011.

GINZBURG, Carlo. Sinais: raízes de um paradigma indiciário. In: GINZBURG, Carlo. Mitos, emblemas, sinais: morfologia e história. 2. ed. Trad. Frederico Carotti. São Paulo: Companhia das Letras, 1989.

GLEDSON, John. Os contos de Machado de Assis: o machete e o violoncelo. In: MACHADO DE ASSIS, Joaquim Maria. Contos: uma antologia. São Paulo: Companhia das Letras, 1998, v. 1.

LIPOVETSKY, Gilles. 0 império do efêmero: a moda e seu destino nas sociedades modernas. Trad. Maria Lucia Machado. São Paulo: Companhia das Letras, 2009.

LUKÁCS, György. Marxismo e teoria da literatura. 2. ed. Seleção, apresentação e tradução de Carlos Nelson Coutinho. São Paulo: Expressão Popular, 2010.

MACHADO DE ASSIS, Joaquim Maria. Ao acaso: revista da semana. Diário do Rio de Janeiro. Rio de Janeiro: 3 jan. 1865, p. 1. Disponível em: http://memoria.bn.br/ DocReader/094170_02/19436. Acesso em: 2 jul. 2019.

MACHADO DE ASSIS, Joaquim Maria. Brincar com fogo. Jornal das Familias. Rio de Janeiro: B. L. Garnier, jul. 1875a, p. 210-215. Disponível em: http://memoria.bn.br/ DocReader/339776/4528. Acesso em: 2 jul. 2019.

MACHADO DE ASSIS, Joaquim Maria. Brincar com fogo (fim). Jornal das Familias. Rio de Janeiro: B. L. Garnier, ago. 1875b, p. 234-240. Disponível em: http://memoria.bn.br/ DocReader/339776/4555. Acesso em: 2 jul. 2019. 
MACHADO DE ASSIS, Joaquim Maria. Um esqueleto. Jornal das Familias. Rio de Janeiro: B. L. Garnier, out. 1875c, p. 289-294. Disponível em: http://memoria.bn.br/ DocReader/339776/4621. Acesso em: 2 jul. 2019.

MACHADO DE ASSIS, Joaquim Maria. Um esqueleto (fim). Jornal das Familias. Rio de Janeiro: B. L. Garnier, nov. 1875d, p. 321-331. Disponível em: http://memoria.bn.br/ docreader/339776/4658. Acesso em: 2 jul. 2019.

MACHADO DE ASSIS, Joaquim Maria. Encher tempo. Jornal das Familias. Rio de Janeiro: B. L. Garnier, abr. 1876, p. 108-116. Disponível em: http://memoria.bn.br/ DocReader/339776/4848. Acesso em: 2 jul. 2019.

MACHADO DE ASSIS, Joaquim Maria. Literatura realista. 0 Cruzeiro. Rio de Janeiro: 16 abr. 1878, p. 1. Disponível em: http://memoria.bn.br/DocReader/238562/657. Acesso em: 2 jul. 1878.

PINHEIRO, Alexandra Santos. O Jornal das Familias (1863-1878) e as leitoras do século XIX. Revista Faz Ciência, Cascavel, v. 6, n. 1, 2004, p. 115-135. Disponível em: http://e-revista. unioeste.br/index.php/fazciencia/article/view/7404/5468. Acesso em: 17 jun. 2015.

PINHEIRO, Alexandra Santos. Para além da amenidade - 0 Jornal das Familias (1863-1878) e sua rede de produções. $279 \mathrm{f}$. Tese (Doutorado) - Instituto de Estudos da Linguagem, Universidade Estadual de Campinas, Campinas, 2007.

SALOMON, Geanneti Tavares. Moda e ironia em Dom Casmurro. São Paulo: Alameda, 2010.

SOUZA, Gilda de Mello e. 0 espírito das roupas. São Paulo: Companhia das Letras, 1987.

VIANA, Fausto. 0 imperador nunca esteve nu. In: ARAÚJO, Marcelo de. Dom Pedro II e a moda masculina na época vitoriana. São Paulo: Estação das Letras e Cores, 2012. 